\title{
Measuring the Quality of the Interim Financial Reports Using the Qualitative Characteristics of the Accounting Information and its Effect on the Investment Decisions According to the "IAS 34"
}

\author{
Hasan Mahmoud AL-Shatnawi ${ }^{1}$ \\ ${ }^{1}$ Department of Accounting, Irbid National University, Jordan \\ Correspondence: Hasan Mahmoud AL-Shatnawi, Department of Accounting, Irbid National University, Jordan. \\ E-mail: hsnshatnawi@gmail.com
}

Received: April 8, 2017

Accepted: April 24, 2017

Online Published: April 30, 2017

doi:10.5539/ijef.v9n5p159

URL: https://doi.org/10.5539/ijef.v9n5p159

\begin{abstract}
This study aimed at measuring the quality of the interim financial reports using the quality characteristics of the accounting information and its effect on the investment decisions according to IAS 34 from the point of view of a category of the financial information users working in the brokerage companies. To achieve the objectives of the study, a questionnaire was designed that contains three constructs related to the primary qualitative characteristics, the enhancing qualitative characteristics, and quality of the interim financial reports. The questionnaire was distributed to a sample consisting of 72 individuals. Descriptive statistics were used to describe the study sample such as the frequencies, arithmetic mean, and standard deviation. In addition, the one-sample t-test and simple linear regression analysis were employed to test the study hypotheses at the 0.05 level of significance. Of the main results which the study reached to are that (i) there is effect of the qualitative characteristics of both the primary and enhancing aspects on the quality of the interim financial reports, and (ii) there is effect of the interim financial reports on the investment decision taking. The study provided a number of recommendations, most important of which is directing the prepares of the interim financial reports to pay attention to providing the qualitative characteristics for the accounting information in the interim financial reports for their positive effect on the quality of these reports to help the decision takers in predicting the economical events and building the future plans.
\end{abstract}

Keywords: primary characteristics, enhancing characteristics, interim financial reports, investment decisions, IAS 34

\section{Introduction}

The financial statements and the clarifications appended to them constitute the main reporting means on which the users of the accounting information depend. The audited annual financial reports are considered as the primary means on which the economical decision takers depend. However, the accelerating changes and successive events through which the establishment goes make the need growing for presence of information that cover time periods shorter than one year. Hence the interim financial reports derive their importance, which keep the accounting information user continuously informed of the results of the works of the establishment and of its financial position, either quarterly or biannually, or even monthly.

For the interim financial reports to be useful for their users, they must be of quality and to have a set of the qualitative characteristics of the accounting information, whether they were primary or enhancing characteristics. Thereupon, these reports are counted as an important source of the information that enable the investors to take their investment decisions and follow up implementation of their plans which they set and correcting them in the suitable time instead of waiting until the end of the year and reading the information which the annual reports present.

As a result of the important role which provision of the information through the interim financial reports plays, and which are considered as an important and main source for the dealers in the financial securities market, and which help them in the decision-taking processes and reduce the degree of uncertainty for them, this study came to measure the quality of the interim financial reports by using the qualitative characteristics of the accounting information and their effects on the investment decisions according to the International Accounting Standard No. 


\section{4 (IAS 34).}

\section{Study Problem}

The decisions of investment in the paper securities depend on the information disclosed in the annual financial reports. Due to length of the time period in the annual reports and so as to fulfill the need of the investors and stakeholders for this information for the purpose of rationalizing their investment decisions and maximize their benefits, the interim financial reports are relied upon. Hence came this study to measure the quality of the interim financial reports by using the qualitative characteristics of the accounting information and their effects on the investment decisions according to the IAS 34. The goal of this study can be achieved through answering the following questions:

1) Is their an effect for the primary characteristics of the financial information on quality of the interim financial reports?

2) Is their an effect for the enhancing qualitative characteristics of the financial information on quality of the interim financial reports?

3) Is their an effect for quality of the interim financial reports on the investment decision making?

\section{Study Objectives}

This study aims at determining whether there is effect for the qualitative characteristics of the accounting information on the quality of the interim financial reports, and, in consequence, on the investment decisions according to the IAS 34 in the shade of their 2010 modifying division into primary characteristics and enhancing characteristics. Consequently, this study sought to achieve the following objectives:

1) To determine the primary qualitative characteristics, represented by the relevance characteristic and the faithful representation characteristic, and to study their effects on the quality of the interim financial reports according to the IAS 34 .

2) Identifying the enhancing qualitative characteristics, represented by the comparability characteristic, verifiability characteristic, understandability characteristic, and the timeliness characteristic, and to study their effects on the quality of the interim financial reports according to the IAS 34.

3) To stand on the effect of the quality of the interim financial reports on the investment decision making.

\section{Study Significance}

This study derives its importance from the phase through which the Jordanian local economy goes in terms of recession in performance of the stock exchanges and drop in their indicators as a result of reluctance of many people to investment in the shares of companies in the shadow of the prevalent conditions, and in view of that the accounting information are considered as a main and important reference for serving many of the decision takers, especially the investors. Thus, this study came to measure the quality of the interim financial reports using the qualitative characteristics of the accounting information and their effects on the investment decisions according to IAS 34 .

\section{Study Hypotheses}

The researcher sought to answer the research questions through the following hypotheses:

First Hypothesis (H1): There is no statistically-significant effect for the primary qualitative characteristics of the accounting information on the quality of the interim financial reports.

Second Hypothesis (H2): There is no statistically-significant effect for the enhancing qualitative characteristics of the accounting information on the quality of the interim financial reports.

Third Hypothesis (H3): There is no statistically-significant effect for the quality of the interim financial reports on the investment decision making.

\section{Study Methodology and Sources of Data}

This study depended on the analytical, descriptive approach and on two sources for data collection:

1) Secondary sources represented by the books, references, periodicals, the international journals, and specialized electronic sites that research into the study subject or include data or information that serve this study.

2) Primary sources: In order to obtain the primary data necessary for testing the hypotheses, a questionnaire was developed and arbitrated. The questionnaire was embodied with a set of questions related to the research 
questions and was distributed to the study sample. Descriptive statistics were used to describe the study sample and the one-sample t-test and simple linear regression analysis were used to test the study hypotheses at the 0.05 level of significance $(\alpha=.05)$.

\section{Previous Studies}

The study of Nurcholisah (2016), titled: "The Effects of Financial Reporting Quality on Information Asymmetry and its Impacts on Investment Efficiency". The financial reporting is the main tool for communicating the financial information to the external parties, which they use as basis for making decisions. The information of the financial statement will have utility value if it is obtained from quality financial reporting. This study was performed in 2012 on 22 pension fund companies in Indonesia. The study results show that quality of the financial reporting did not influence the asymmetric information, which itself did not influence efficiency of the investments.

The study of Rahmani and Jabari (2015), titled: "A Model for Evaluating the Impacts of Qualitative Characteristics on the Usefulness of Financial Reporting". This study aimed at investigating the impacts of the qualitative characteristics on usefulness of the financial reporting. The study used structural equations modeling (SEM) for analysis of the data. The SPSS, PLS, and LISREL software were employed in an effort to test the research reliability, model, and research validity, respectively. Data on a sample of 185 companies over the period 2000 to 2013 were employed. Except for the understandability, the qualitative characteristics did not have any effect on usefulness. On the other hand, conservatism had negative influence on usefulness. On the basis of these results, the researchers recommended omitting conservatism from the qualitative characteristics. In addition, taking into consideration that relevance has higher effect on usefulness than on reliability, it may be concluded that users of the financial statements are looking for suitable information in their own decision-making process and reliability of the information is an issue of secondary importance.

The study of Albawwat and Basah (2015), titled: "Corporate Governance and Voluntary Disclosure of Interim Financial Reporting in Jordan". This study delved into the relation between the corporate governance characteristics and the ownership structure on the voluntary disclosure in the financial reports published on an interim basis, concentrating on the variables which influence the voluntary disclosure of the Jordanian companies listed on Amman Stock Exchange Market (ASEM). The dynamic panel system GMM estimation was applied to data pertaining to 72 selected companies listed on ASEM in the period 2009-2013. The analysis results indicated manifestation of remarkable degree of voluntary disclosure by a high level of awareness and implementation of corporate governance in Jordan. In specific, the factors of audit firm size, government ownership, and board compensation did significantly influence the voluntary disclosure. Apart from that, the study found that voluntary disclosure in the biannual reports has a potential effect on the market capitalization.

The study of Chim and Anca (2014), titled: "Financial Accounting Quality and its Defining Characteristics" The main aim of this qualitative study was to determine the characteristics which the information should possess so as to be of a high quality. These characteristics contribute to the way how quality of the financial accounting is defined. The methodology of this study consisted of reviewing the literature relating to definition of the accounting quality and attempting to understand how it can be explained. The main conclusions drawn by this research were that (i) the quality of the financial accounting can not be defined in a unique manner, and (ii) the financial information is of a good quality when it improves the characteristics incorporated into the conceptual frameworks issued by the Financial Accounting Standards Board (FASB) and the International Accounting Standards Board (IASB).

The study of Imam and Zamil (2014), titled: "Effect of the Informational Content of Interim Financial Reports on Stock Prices: An Empirical Study of a Sample of Banks Listed on the Iraq Stock Exchange". This study aimed at identifying the influence of the information presented in interim financial reports on the stock prices, and the importance of information for the investors' decisions. The study sample consisted of banks listed on Iraq Stock Exchange Market in order to determine the extent to which the informational content of the interim financial reports contributes to the stock prices. Data analysis and hypothesis testing indicated that there are no significant relationships between the moral effects, informational content of the interim financial reports, and the trading indicators during the period of issuance of interim financial reports. This study thus reached to several conclusions, including that the aim of preparing interim financial reports is to provide financial information in a shorter period of time than one year, which the Securities Commission requires the companies listed on this capital market to do. This commission requires the listed companies to issue information to the investors and other stakeholders and users. Issuance of interim financial reports by the companies listed on Iraq Stock Exchange Market was not only posed on the listed companies after release of the instructions No. (8) in the year 
2010 for the disclosure of the listed companies. These researchers gave several recommendations, including fostering awareness among the investors of importance of information contained in interim financial reports as one of the principal sources of information relied upon by the creditors and investors in making their decisions.

The study of Majumder et al., (2012), titled: "Perceptions of Bangladeshi Investors on the Usefulness of Interim Financial Reports". This work provides an insight into perceptions of the Bengali investors of usefulness of the interim financial reports. These perceptions were solicited by using the questionnaire survey approach. The study provides evidence on that the interim financial reports are regarded as more useful than the annual reports. As well, this study found that the Bengali investors depend on the interim financial reports for estimation of the future annual results. In addition, the study found that the earning per share and the prospects of the present year are the most useful disclosure items in the interim financial reports. This study indicates that importance of the interim financial reporting will depend on the kind of the investors.

The study of Ismail and Abdul Rahman (2011), titled: "The Wealth of Information from Quarterly Financial Reports in Malaysia". This study aimed at examining the wealth of information of the quarterly financial reports in Malaysia with respect to performance of the share prices at the disclosure time. In specific, the study explored whether level of disclosure of the quarterly reports and changes in earnings in the past quarter do, or do not, influence the performance of the share prices of firms. The study employed a sample consisting of 304 quarterly report announcements from the top 76 firms according to market capitalization and which are listed on the main board of Bursa Malaysia in the 2005 financial year. The event study approach was employed in order to examine the information content of the quarterly financial report announcements. The results of this study showed that the public listed firms in Malaysia disclosed information extensively in their quarterly reports, in accordance with the requirements. The only hypothesis that was supported was the hypothesis of a positive relation between performance of the share prices of the firms and changes in the earnings. This suggests that the investors mainly consider the data on the earnings in the quarterly reports rather than the other disclosures.

Nurcholisah (2016), Rahmani and Jabari (2015), Chim and Anca (2014) had been studies the importance of improving the quality of the annual financial reports through the availability of the quality characteristics of the accounting information and the role of these reports in the efficiency of investment and where there was a discrepancy between the results of these studies and the reason for the difference in tools used and the environment applied to the study. Albawwat and Basah (2015), Imam and Zamil (2014), Majumder et al. (2012), Ismail and Abdul Rahman (2011) had been studies the importance of the interim financial reports with its useful and important information. The interim financial reports are considered one of the most important sources for investors in order to help him in getting the accounting information for decisions making.

Therefore, this study explains the effect of the qualitative characteristics of the accounting information on the quality of the interim financial reports, by studying the primary qualitative characteristics, the enhancing qualitative characteristics according to the conceptual framework for financial reporting which modified on 10th of 2010. And then measuring their impact on the investment decisions with a test of a sample of investment professionals.

\section{Theoretical Framework of the Study}

\section{First: The Interim Financial Reports}

The financial reports are considered as one of the most important sources through which the stakeholders of the project get the information which they need to help them in taking their different decisions. These reports are considered as the main means of disclosure of the financial and non-financial accounting information. Although the financial lists are the principal means of providing the information to its users, they are part of the financial report. In consequence, the financial report extends to include - besides the financial lists - the report of the board of directors to the shareholders, the discussions and analyses of the administration, subscription bulletins, the predictions and forecasts of the administration, and the environmental and social role of the works of the establishment. Such information is included in the financial reports in response to legal requirements or by rule of the principles or disclosure of that information for desire of the administration (Kieso et al., 2012).

In view of the accelerating changes and the successive events through which the companies go, they do not any more find it enough to issue the yearly reports as the need increased for presence of information that cover periods of time shorter than one year. Hence the financial reports derive their importance since they keep the users of the accounting information continuously informed of the results of the operation of the company and its financial position, either annually, biannually, or monthly (Al-Khateeb, 2009).

The IAS 34 defined the interim financial reports as a financial report that includes either a complete set or a 
summary of the financial data for an interim period, and it defined the interim period as the period of preparing financial reports that is shorter than a complete financial year (Mirza et al., 2008). Therefore, the following properties of the interim financial report can be extracted (Baekdh, 2012):

1) The period about which the report is prepared must be shorter than a complete financial year. It may be half a year, or quarter of a year, or a month.

2) These reports differ from those reports that are prepared for special purposes or that are prepared for internal use, even if they were characterized by periodicity.

3) The interim financial reports are intended both for internal and external use.

4) The interim financial reports are not a substitute for the annual financial lists but complementary to them.

5) The purpose of the interim financial reports is to supply the financial list users with the information which helps them in taking better decisions under the circumstances of uncertainty in the capital markets.

6) The interim financial reports provide the accounting data with the characteristics of convenience (appropriateness) and the appropriate timing (timeliness) for decision taking.

According to IAS 34, the goal of this standard is describing the minimum limit of the content of the interim financial reports and describing the admission and measurement principles in the short or the complete financial lists for a certain interim financial period, which contributes to reinforcement of the users' use of the accounting information in taking rational decisions (Abo Nassar \& Homaydaat, 2016).

\section{Second: The Qualitative Characteristics of the Accounting Information}

In 1989, the board of IAS published the conceptual framework under the name of a framework for the preparation and presentation of the financial statements. This framework to some extent resembles the conceptual framework set by the FASB and which many countries set, e.g., Australia, New Zealand, and Canada.

As regards the international financial reporting standards/the international accounting standards, they have been accredited and adopted in the European Union countries and many other world countries by the beginning of the year 2005. However, there is a criticism directed to the board of the IAS stating that the conceptual framework needs many updates and improvements to be like a guide and director when setting the accounting standards (Al-Saeed, 2008).

The characteristics of the accounting information represent the main characters that enable this information to achieve the goals of the financial reports and there is no specific number of the characteristics of the accounting information such that once they are available the financial reporting is of high quality. The IASB specified these characteristics and they have been divided into primary characteristics (relevance and faithful representation) and enhancing characteristics (comparability, verifiability, timeliness, and understandability).

It is meant by the relevance characteristic that the presented financial information is relevance. This information must be related to the decision and, consequently, affect the economical decisions of the users and make a difference in those decisions. This information possesses the relevance characteristic when it affects economical decisions of the users by helping them in evaluating the past, present, and future events or enhance or correct their past evaluations and increase their ability to predict the events (Abo Nassar \& Homaydaat, 2016). The information is considered of relative importance if its omission or falsification can affect the economical decisions which the users take depending on the financial data (Jomaah, 2010).

The faithful representation characteristic points to symmetry between the accounting information and the events, which target this information to represent (Balkawi, 2009). For the information to assume the characteristic of credibility, it must reliably represent the financial operations and other events which it is understood to portray or is expected to express reasonably (Lotfi, 2008). So as to represent the information in a reliable way, it must be complete, not deficient, and neutral, not biased, and devoid of the material errors.

The primary characteristics of the accounting information are supported by a set of the qualitative characteristics represented by the comparability characteristic, which means the possibility of comparing the financial statements for a certain period with the financial statements of other past period(s) for the same establishment, or comparing the financial statements of an establishment with the financial statements of another establishment for the same period. The users of the accounting information benefit from holding comparisons for the purposes of taking the decisions related to the investment and financing decisions, and tracking the performance and financial position of the establishment from period to another, and holding comparisons among the different establishments (Abo Nassar, 2016). 
The verifiability characteristic means helping the users of the financial reports to confirm that the information representation in the financial reports was reliable. It also means that the information whose soundness and reliability are verified is the information which can be entirely regenerated by independent individuals who perform measurement using the same measuring procedures (Balkawi, 2009).

The timeliness characteristic means that the information is available for decision taking when it has an effect on the decision. To achieve this criterion, the financial lists must be prepared and sent to the investors and debtors in sufficient time before they take their decisions (Addahrawi, 2009).

The understandability characteristic means classification and presentation of the information clearly and accurately. It is assumed that the accounting information users have a reasonable level of knowledge in the domain of accounting and in the operation and economical activities of the establishment and that they have the desire in exerting the adequate effort to study the accounting information presented in the financial reports of the company. Furthermore, the presented financial information must be far from complication and difficulty (Abo Nassar \& Homaydaat, 2016).

\section{Third: Need of the Investment Decision Takers for the Accounting Information in the Interim Financial Reports}

Accounting is termed as the language of business. It is one of the sciences which cares about measurement, recording, and analysis of the information, and about delivering the information which result from them in the form of financial reports to the beneficiary parties of the accounting information users for using it in rational decision making.

The investor needs the information that enables her/him to take the right investment decisions. Therefore, the investor resorts to the information sources that provide her/him with the relevant information to take her/his decision. The information sources to which the investor resorts multiply; they may be the financial reports, the interim reports, the daily magazines and newspapers, the economical bulletins in the TV, the electronic websites specific to the shares, the rumors, or other sources (Baekdh, 2012).

The most important information which the investor needs concentrates in three main aspects in addition to the historical information appearing in the financial reports. These are (Al Sowayd, 2000):

1) The future economical vision of the establishment in which the investor desires to invest her/his money.

2) The future economical vision of the industry which the establishment is considered as part of.

3) Quality of the administration as success or failure of any establishment depends on the quality of its administration.

Publication of the interim financial reports in the suitable time is considered as an important element for increasing the benefit of the accounting data and information for their users. Therefore, the accounting information appearing in the interim financial reports should be taken with a lot of caution and one must not rush in taking the important or decisive investment decisions.

\section{Study Population and Sample}

The study population includes all the investment specialists in the registered brokerage companies, which amounted to 58 companies during the field study period according to the Securities Deposition Center. A random sample of 85 specialists was taken and the questionnaire was distributed to them. Seventy-two of those questionnaire forms were responded to. They were all complete and valid for performing the study on them.

\section{Statistical Results}

\subsection{The Reliability Test}

The researchers performed a test of reliability of the instrument of this research (questionnaire) using the relaibility test and Cronbach's Alpha coeffieint as an indicator of relaibility. The analysis results indicate that the research instrument has a Cronbach's Alfa coefficient of 0.889. In addition to being higher than the lower limit of Cronbach's Alfa coefficient that is accepted for research, which is 0.70 (Hair et al., 2006), this value (0.857) indicates an excellent level of reliability.

\subsection{Analysis of the Characteristics of the Study Sample}

Tables 1-3 give a description of the study sample, which can be clarified as follows:

1) Description of the study sample according to the academic qualitfication (Table 1):

Table 1 shows that the highest percentage of the respondents $(51.4 \%)$ was for those holding a bachelor's 
qualification while the lowset percentage of respondents $(6.9 \%)$ was for those holding a secondary school qualification or lower.

Table 1. Distribution of the sample members according to academic qualification

\begin{tabular}{ccc}
\hline Academic Qualification & Frequency & Percentage \\
\hline Secondary school or lower & 5 & $6.9 \%$ \\
Intermediate College Diploma & 12 & $16.7 \%$ \\
Bachelor & 37 & $51.4 \%$ \\
Graduate Studies & 18 & $25.0 \%$ \\
\hline Total & 72 & $100 \%$ \\
\hline
\end{tabular}

2) Description of the study sample according to years of experience in the domain of investment

Table 2 reveals that the highest percentage of the respondents $(41.7 \%)$ was for those whose experience in the domain of investment ranges from 10 to less than 15 years. Meantime, the lowset percentage of respondents $(11.1 \%)$ was for those whose experience in the domain of investment is less than 5 years.

Table 2. Distribution of the sample members according to years of experience in the domain of investment

\begin{tabular}{ccc}
\hline Practical Experience & Frequency & Percentage \\
\hline$<5$ Years & 8 & $11.1 \%$ \\
$5-<10$ years & 18 & $25.0 \%$ \\
$10-<15$ years & 30 & $41.7 \%$ \\
$\geq 15$ Years & 16 & $22.2 \%$ \\
\hline Total & 72 & $100 \%$ \\
\hline
\end{tabular}

3) Description of the study sample according to frequency of following up the international accounting standards

Table 2 uncovers that the highest percentage of the respondents $(48.6 \%)$ was for the people who mostly follow up the international accounting standards. Meanwhile, the lowset percentage of respondents $(2.8 \%)$ was for the respondnets who follow up the international accounting standards to a limited extent.

Table 3. Distribution of the sample members according to frequency of following up the international accounting standards

\begin{tabular}{ccc}
\hline Frequency of Following up the IASs & Frequency & Percentage \\
\hline Continuous & 20 & $27.8 \%$ \\
Frequent & 35 & $48.6 \%$ \\
Moderate & 15 & $20.8 \%$ \\
Low & 2 & $2.8 \%$ \\
\hline Total & 72 & $100 \%$ \\
\hline
\end{tabular}

\subsection{Description of the Answers of the Sample Members}

Tables 4-6 provide a descriptve presentation of the answers of the sample respondnets to every questionnaire item that shows the arithmetic mean, standard deviation, and rank for the answers to each item individually. The results given in these tables can be presebted as follows:

Table 4 is related to effect of the primary qualitative characteristics of the accounting information on quality of the interim financial reports. The responses tend to agreement because the mean responses are all greater than 3.00. On the other hand, the first item, which states that the information appearing in the interim financial reports are suitable for all the users of the financial reports, had the highest agreement rank since its mean score is 4.12 and its standard deviation is 0.71 . 
Table 4. The arithmetic means and standard deviations of the items related to effect of the primary qualitative characteristics of the accounting information on quality of the interim financial reports

\begin{tabular}{|c|c|c|c|c|}
\hline No. & Item & Mean & S.D & Rank \\
\hline 1 & $\begin{array}{l}\text { The information appearing in the interim financial reports are suitable for all the users of the financial } \\
\text { reports. }\end{array}$ & 4.12 & .71 & 1 \\
\hline 2 & $\begin{array}{l}\text { The interim financial reports include information that helps in the expectations and predictions related } \\
\text { to growth of the establishment. }\end{array}$ & 3.70 & .90 & 2 \\
\hline 3 & $\begin{array}{l}\text { The interim financial reports present a confirmatory value of the important events and bargains related } \\
\text { to the market and which affected the company. }\end{array}$ & 3.56 & .92 & 4 \\
\hline 4 & $\begin{array}{l}\text { The interim financial reports show the non-financial information together with the financial to help in } \\
\text { the expectations and predictions related to the future of the company. }\end{array}$ & 3.63 & .93 & 3 \\
\hline 5 & $\begin{array}{l}\text { The company sheds light when preparing the interim financial reports on each of the positive and } \\
\text { negative events. }\end{array}$ & 3.49 & .95 & 6 \\
\hline 6 & The information which the interim financial reports include lack important essential errors. & 3.36 & .89 & 8 \\
\hline 7 & The interim financial reports are characterized by neutrality and non-bias. & 3.38 & .86 & 7 \\
\hline 8 & $\begin{array}{l}\text { The interim financial reports present truthful facts without omission or selection of information for the } \\
\text { interests of certain categories. }\end{array}$ & 3.5 & 1.11 & 5 \\
\hline & Overall Mean & 3.65 & 0.45 & - \\
\hline
\end{tabular}

Note. SD: Standard Deviation.

Table 5 relates to effect of the enhancing qualitative characteristics of the accounting information on quality of the interim financial reports. The analysis results listed in this table uncover that the responses are inclined to agreement owing to that the mean responses are all higher than 3.00. On the other hand, the eighth item, which states that the interim financial reports of the company are published within the legal period in which publication of the report is allowed, is the item with the highest agreement rank as its mean score is 4.36 and its standard deviation is 0.74 .

Table 5. The arithmetic means and standard deviations of the items related to effect of the enhancing qualitative characteristics of the accounting information on quality of the interim financial reports

\begin{tabular}{|c|c|c|c|c|}
\hline No. & Item & Mean & S.D & Rank \\
\hline 1 & $\begin{array}{l}\text { The company presents the standard figures and financial ratios in the interim } \\
\text { financial reports. }\end{array}$ & 3.43 & .90 & 5 \\
\hline 2 & $\begin{array}{l}\text { The information appearing in the interim financial reports are compared with the } \\
\text { information which the other companies present. }\end{array}$ & 3.08 & .98 & 8 \\
\hline 3 & $\begin{array}{l}\text { The interim financial reports include arguments that support the assumptions and } \\
\text { assessments appearing in them. }\end{array}$ & 3.31 & 1.14 & 6 \\
\hline 4 & $\begin{array}{l}\text { The interim financial reports clarify the ways of applying the accounting standards } \\
\text { and present pretexts for them. }\end{array}$ & 3.54 & .93 & 4 \\
\hline 5 & $\begin{array}{l}\text { The interim financial reports are presented in an organized and clear way, away } \\
\text { from complication and difficulty. }\end{array}$ & 3.83 & 1.02 & 3 \\
\hline 6 & $\begin{array}{l}\text { The interim financial reports present information that is characterized by } \\
\text { smoothness and ease. }\end{array}$ & 4.10 & .79 & 2 \\
\hline 7 & $\begin{array}{l}\text { The clarifications of, and notes on, the interim financial reports are considered as } \\
\text { clear enough. }\end{array}$ & 3.21 & .82 & 7 \\
\hline 8 & $\begin{array}{l}\text { The interim financial reports of the company are published within the legal time } \\
\text { limit in which publication of the reports is allowed. }\end{array}$ & 4.36 & .74 & 1 \\
\hline & Overall Mean & 3.61 & .53 & - \\
\hline
\end{tabular}

Note. SD: Standard Deviation.

Table 6 pertains to the effect of quality of the interim financial reports on the investment decisions. The analysis outcomes introduced by this table disclose that the responses of the sample members tend to agreement due to that all the mean responses are higher than 3.00. On the other hand, the fifth item, which states that the accounting information must be delivered to the interested people in the suitable time for it to help them in taking the decision, is the item receiving the highest agreement rank because its mean agreement score is 4.04 and its standard deviation is 0.72 . 
Table 6. The arithmetic means and standard deviations of the items related to effect of the quality of the interim financial reports on the investment decisions

\begin{tabular}{|c|c|c|c|c|}
\hline No. & Item & Mean & S.D & Rank \\
\hline 1 & The interim financial reports contain suitable information for taking the appropriate decisions. & 3.60 & 1.06 & 5 \\
\hline 2 & $\begin{array}{l}\text { The interim financial reports provide information of predictive ability that helps the investors in } \\
\text { taking the decisions. }\end{array}$ & 3.18 & 1.09 & 8 \\
\hline 3 & $\begin{array}{l}\text { The interim financial reports provide information that is adequate to help the users of the financial } \\
\text { reports in taking decisions. }\end{array}$ & 3.50 & 1.00 & 7 \\
\hline 4 & $\begin{array}{l}\text { Preparation of the interim financial reports according to the international standards for preparation } \\
\text { of the financial reports leads to provision of correct information for the decision taker. }\end{array}$ & 3.86 & .98 & 2 \\
\hline 5 & $\begin{array}{l}\text { The accounting information must be delivered to the interested people in the suitable time for it to } \\
\text { help them in taking the decision. }\end{array}$ & 4.04 & .72 & 1 \\
\hline 6 & $\begin{array}{l}\text { The verifiability characteristic enables confirming and verifying the information appearing in the } \\
\text { interim financial reports which can be relied on in taking the decision. }\end{array}$ & 3.64 & .95 & 4 \\
\hline 7 & Understanding the interim financial reports helps in making the decision taking easier. & 3.53 & 1.00 & 6 \\
\hline 8 & $\begin{array}{l}\text { The interim financial reports provide accounting information that lead to increasing the ability } \\
\text { and skills of the decision takers. }\end{array}$ & 3.75 & 1.04 & 3 \\
\hline & Overall Mean & 3.59 & .44 & - \\
\hline
\end{tabular}

Note. SD: Standard Deviation.

\subsection{Hypothesis Testing}

Hypothesis 1: There is no statistically-significant effect for the primary qualitative characteristics of the accounting information on the quality of the interim financial reports.

The researchers tested soundness of this hypothesis using the one-sample t-test. The analysis results given in Table 8 reveal that the calculated value of the $t$ statistic is 12.198 . This value is actually higher than the respective tabulated value; 1.96 . Thus, the null hypothesis is rejected in favor of the alternative hypothesis, which is accepted. In consequence, the researchers conclude that the primary qualitative characteristics of the accounting information have statistically-significant effect on the quality of the interim financial reports at the level of significance of 0.05 .

Table 7. Sample statistics (one-sample statistics)

\begin{tabular}{ccccc}
\hline & $\mathrm{N}$ & Mean & Std. Deviation & Std. Error Mean \\
\hline H1 & 72 & 3.6528 & .45445 & .05356 \\
\hline
\end{tabular}

Table 8. Results of t-test (one-sample test)

\begin{tabular}{ccccccc}
\hline & & & \multicolumn{2}{c}{ Test Value $=3.5$} \\
\hline & \multirow{2}{*}{$\mathrm{t}$} & $\mathrm{df}$ & Sig. (2-tailed) & Mean Difference & \multicolumn{2}{c}{$95 \%$ Confidence Interval of the Difference } \\
\cline { 6 - 7 } & & & & Lower & Upper \\
\hline H1 & 12.188 & 71 & .000 & .6528 & .5460 & .7596 \\
\hline
\end{tabular}

Second Hypothesis (H2): There is no statistically-significant effect for the enhancing qualitative characteristics of the accounting information on the quality of the interim financial reports.

The researchers tested this hypothesis using the one-sample t-test. Outcomes of hypothesis testing (Table 10) indicate that the calculated value of the $t$ statistic is 9.690, which is higher than the corresponding tabulated value, that is, 1.96. Therefore, the null hypothesis can be rejected and the alternative hypothesis is accepted. Accordingly, the researchers reach to the conclusion that the enhancing qualitative characteristics of the accounting information have statistically-significant effect on the quality of the interim financial reports at the 0.05 level of significance.

Table 9. Sample statistics (one-sample statistics)

\begin{tabular}{ccccc}
\hline & $\mathrm{N}$ & Mean & Std. Deviation & Std. Error Mean \\
\hline $\mathrm{H} 2$ & 72 & 3.6094 & .53361 & .06289 \\
\hline
\end{tabular}


Table 10. Results of t-test (one-sample test)

\begin{tabular}{lllcccc}
\hline & & \multicolumn{5}{c}{ Test Value $=3.5$} \\
\hline & \multirow{2}{*}{$\mathrm{t}$} & $\mathrm{df}$ & & Sig. (2-tailed) & Mean Difference & \multicolumn{2}{c}{ 95\% Confidence Interval of the Difference } \\
\cline { 5 - 7 } & & & & Lower & Upper \\
\hline H2 & 9.690 & 71 & .000 & .6094 & .4840 & .7348 \\
\hline
\end{tabular}

Third Hypothesis (H3): There is no statistically-significant effect for the quality of the interim financial reports on the investment decision taking.

This hypothesis was tested using simple linear regresion analysis. Table 11 shows that significance of the test statistics has a value of 0.00 , which is less than 0.05 . This means rejection of the third null hypothesis and acceptance of the associated alternative hypothesis, which indicates presence of statistically-significant effect of the quality of the interim financial reports on the investment decision taking. Moreover, Table 11 reveals lack of differences in the answers because the calculated value of the F statistic (10.533) is higher the the related tabualted value, and it is statistically significant. The analysis outputs also show that the quality of the interim financial reports explains $13.1 \%$ of the variations between the respondents in their investment decision taking, which is a somewhat low percentage.

Table 11. Sample statistics (simple linear regression)

\begin{tabular}{ccccc}
\hline & $\mathrm{N}$ & Mean & Std. Deviation & Std. Error Mean \\
\hline $\mathrm{H} 3$ & 72 & 3.5920 & .44156 & .197 \\
\hline
\end{tabular}

Table 12. Results of F-test (simple linear regression).

\begin{tabular}{ccccccc}
\hline & \multicolumn{7}{c}{ Test Value $=3.5$} \\
\cline { 2 - 7 } & Sig. (2-tailed) & df & R Square & F & T & Factor coefficient \\
\hline H3 & .000 & 71 & .131 & 10.553 & 3.249 & .362 \\
\hline
\end{tabular}

\section{Study Conclusions}

In view of the statistical results to which this study reached, the most important conclusions of the study can be presented as follows:

1) The primary qualitative characteristics of the accounting information affect to a great degree improvement of the quality of the interim financial reports. In consequence, these reports must be characterized by a set of the primary characteristics, which are relevance and faithful representation, so that this information can be influential in decision taking and honestly express the financial operations.

2) The enhancing qualitative characteristics of the accounting information influence, to a great degree, improvement of the quality of the interim financial reports. Consequently, these reports must be characterized by a group of the enhancing characteristics, which are comparability, verifiability, understandability, and the timeliness characteristics.

3) The decisions of the users of the financial reports are influenced by the quality of the interim financial reports, which is represented by the characteristics of the accounting information, whether those properties are primary or enhancing. Thereupon, lack of those characteristics in the interim financial reports is due to reflect, in a passive way, on quality of the taken decision and on the benefit which may be realized as a result of it.

\section{Recommendations}

In the light of the study conclusions, this study recommends what follows:

1- Directing the preparers of the interim financial reports to care about providing the qualitative characteristics of the accounting information in the interim financial reports because of the positive effects they have on the quality of these reports so as to help the decision takes in predicting the economical events and building the future plans.

2- Caring about propagating the culture of awareness among the investors of the importance of the information which the interim financial reports contain, considering it as one of the most important sources of the information on which the investors and debtors depend in taking their decisions. 
3- Preparing the seminars and workshops that lead to increasing the awareness of the interim financial reports among the investors, debtors, and others of the accounting information users.

\section{References}

Abo Nassar, M., \& Homaydat, J. (2016). The international standards of accounting and financial reporting. Dar Wael for Publishing, Distribution, and Packaging (3rd ed.). Amman, Jordan.

Abo Nassr, M. (2016). Intermediate accounting. Dar Wael for publishing and distribution, and packaging (1st ed.). Amman, Jordan.

Achim, A, M., \& Chiş, A. O. (2014). Financial Accounting Quality and Its Defining Characteristics. EA Practical Application of Science, 3(5).

Addahrawi, K. M. (2009). The intermediate accounting according to the financial accounting standards (2nd ed.). The Modern Academic Office. Alexandria, Egypt.

Al Sowayd, M. M. (2000). Effect of The Financial Information Published in the Annual Reports on the Share Trading Volume and Investor's Behavior: A Field Study of the Industrial Shaerholding Companies. Unpublished Master's Thesis. King Abdul Aziz University, Jeddah, the Kingdom of Saudi Arabia.

Albawwat, A. H., \& Basah, M. Y. (2015). Corporate Governance and Voluntary Disclosure of Interim Financial Reporting in Jordan. Journal of Public Administration and Governance, 5(2). https://doi.org/10.5296/jpag.v5i2.7580

Al-Imam, S. M., \& Zamil, I. A. (2014). Effect of The Informational Content of Interim Financial Reports in Stock Prices an Empirical Study of a Sample of Banks Listed on the Iraq Stock Exchange. Qadisiya Journal of Administrative and Economic Sciences, 2(16).

Al-Khateeb, K. (2009). Standard number 34: the interim financial reports. training program on the international standards for preparation of the financial reports within the scientific activities of the financial securities and exchange markets committee in cooperation with the society of the syrian chartered accountants. Damascus University.

Assaeed, M. (2008). Effect of Disclosure Using the Fair Value Concept in the Light of the Changes in The International Financial Reporting Standards on the Financial Reporting in the Jordanian Insurance Companies. Unpublished Phd dissertation. Amman University for Graduate Studies. Amman, Jordan.

Baekdh, R. (2012). The Impact of Accounting Information Contained in The Interim Financial Reports on Stock Prices (Applied Study on Saudi Stock Market). Unpublished Master's Thesis, King abdul Aziz University, Jeddah, the Kingdom of Saudi Arabia.

Balkawi, A. (2009). An Accountancy Theory (1st ed.). Al Yazori Scientific House for Publishing and Distribution. Amman, Jordan.

Hair, J., Anderson, R., Tatham, R., \& Black, W. (2006). Multivariate Data Analysis (6th ed.). Prentice-Hall, Upper Saddle River.

Ismail, K., \& Abdul, R. R. (2011). The Wealth of Information From Quarterly Financial Reports in Malaysia. African Journal of Business Management, 5(30).

Jomaah, A. H. (2010). The Financial Accounting Theory (1st ed.). Dar Safa for Publishing and Distribution, Amman, Jordan.

Kieso, D. E., Weygandt, J. J., \& Warfield, T. D. (2012). Intermediate Accounting. New York: Johan Wiely and Sons, Inc.

Lotfi, A. S. A. (2008). Preparation and Presentation of the Financial Lists in the Light of the Accounting Standards. Eldar Eljamaya for Publishing and Distribution, Alexandria, Egypt.

Mackenzie, B., Coetsee, D., Njikizana, T., Chamboko, R., Colyvas, B., \& Hanekom, B. (2012). Wiley IFRS 2013: Interpretation and Application of International Financial Reporting Standards. John Wiley \& Sons.

Majumder, M. T. H., Rahman, M. M., \& Rahman, M. M. (2012). Perceptions of Bangladeshi investors on the usefulness of interim financial reports. School of Doctoral Studies (European Union) Journal, 24-29.

Nurcholisah, K. (2016). The Effects of financial reporting quality on information asymmetry and its impacts on investment efficiency. International Journal of Economics, Commerce and Management, 5(5).

Rahmani, H., \& Jabari, H. (2015). A Model for Evaluating the Impacts of Qualitative Characteristics on the 
Usefulness of Financial Reporting. International Journal of Management, Accounting and Economics, 2(4).

\section{Copyrights}

Copyright for this article is retained by the author(s), with first publication rights granted to the journal.

This is an open-access article distributed under the terms and conditions of the Creative Commons Attribution license (http://creativecommons.org/licenses/by/4.0/). 